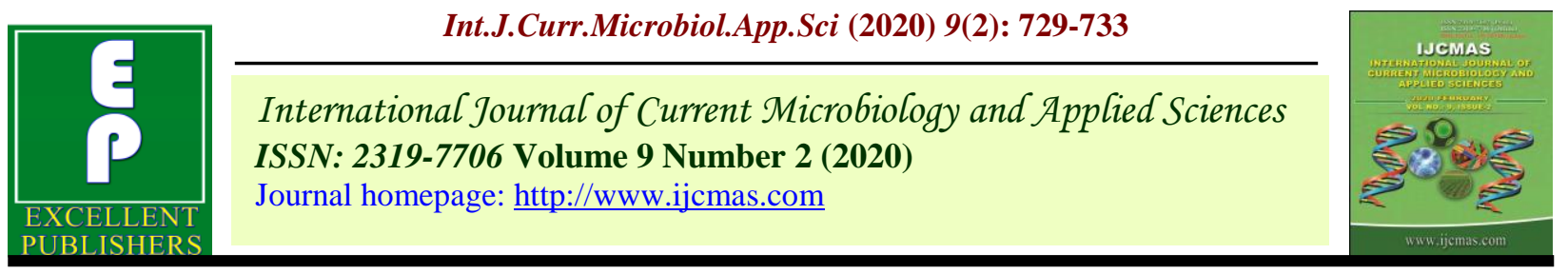

Review Article

https://doi.org/10.20546/ijcmas.2020.902.089

\title{
Agricultural Methane Emissions: Consequences and Mitigations
}

\author{
Jencymol Thomas ${ }^{1 *}$, Arun Kumar ${ }^{2}$ and Ashvani Kumar ${ }^{2}$ \\ ${ }^{1}$ University Institute of agricultural sciences, Chandigarh University, Gharuan, Mohali, \\ Chandigarh-140413, India \\ ${ }^{2}$ School of Agriculture, Lovely Professional University, Phagwara, Punjab-144411, India \\ *Corresponding author
}

\section{A B S T R A C T}

Keywords

Methane emission, Consequences, Mitigation strategy

Article Info

Accepted:

08 January 2020

Available Online:

10February 2020
Rice is an unavoidable diet of most of the human beings and it is grown all over the world. But the production of rice contributes a great portion of methane emissions on annual basis. The methane which is produced contributes to climate change. Not only had the production of rice crop but also different agricultural processes contribute to the climate change. The sources of methane emission from the agriculture are wetland, termites, vegetation, ruminants, manure, and natural gas etc. In this review we present the different types of methane emission from agriculture, their consequences and mitigations.

\section{Introduction}

Rice feeds almost 60 percent of the world's population. It is a dominant crop in the Asian region and probably the first cultivated crop in Asia. The importance of rice to national food security is increasing day by day. But unfortunately rice fields contribute almost 20 percent or $\sim 100 \mathrm{Tg} \mathrm{CH}_{4}$ to the global methane emissions on an annual basis (Houghton et al., 1996, Adhya et al., 2000). Methane is a green house gas and is a major hydrocarbon with an average concentration of $1.7 \mathrm{ppm}$ present in the atmosphere. Methane will be present in the atmosphere for about 10 years and is more capable of absorbing infrared radiation so that it is more efficient than $\mathrm{CO}_{2}$ as a green house gas (Blake and Rowland, 1988).

Methane was first identified in late $18^{\text {th }}$ century by an Italian physicist Alessandro Volta (Smith et al., 2010). Methane is used throughout the world as industrial and domestic fuel source and it has helped as an alternate for other higher carbon energy sources. Methane is transferred from soil to the atmosphere is mainly by the aerenchyma of aquatic plants. The air bubbles from wetland are also a source of methane transfer to the atmosphere. The sources for methane production are from natural as well as anthropogenic sources. The natural sources include wetlands, termites, oceans, wild 
animals, and wild fires. The anthropogenic sources are coal mining, industries like gas and oil, ruminants, rice agriculture and biomass burning. Methane is produced in the submerged soil by methanogenic bacteria in anaerobic conditions (Le Mer and Roger, 2001). Many bacteria's are involved in this process but the final stage is controlled by the methane producing bacteria called methanogens. Methanogens produce methane through the process called methanogenesis in which methane and carbon dioxide is formed by the following reaction.

$\mathrm{C}_{6} \mathrm{H}_{12} \mathrm{O}_{6} \breve{3} \mathrm{CO}_{2}+3 \mathrm{CH}_{4}$

This reaction occurs in anaerobic environments where sulphate and nitrate concentrations are low. The process requires the action of four populations of microbes which convert the complex organic form into simpler. They are hydrolytic microflora which helps in the hydrolysis of biological polymers into monomers like glucides, fatty acids and amino acids. The another group of bacteria's are fermentative microflora which helps in the production of volatile fatty acids, organic acids, alcohols, $\mathrm{H}_{2}$, and $\mathrm{CO}_{2}$ from the monomeric compounds. Homoacetogenic microflora produces acetogenesis. The last populations of bacteria are methanogens which dominates the reactions from the simple compounds. Methanogenic bacteria have a great number of populations in rice fields, forest and water logged upland soils (Mayer and conrad, 1990).

\section{Source of Methane emission}

\section{Wetlands}

Methane emissions from wetland are estimated around one quarter of global methane emissions. Methane consumption from wetlands is mainly performed by a group of microorganisms called methanotroph (Cicerone and Oremland, 1988). Emission of methane from wetlands are mainly determined by temperature (Christensen et al., 2003), water table depth (MacDonald et al., 1998) and substrate availability (Christensen et al., 2003).

\section{Termites}

Not all termite species produce methane but only few. Soil feeding termites emit more methane than wood feeders (Bignell and Eggleton, 2000). Some of the termite colonies produce gases like $\mathrm{CO}_{2}, \mathrm{CH}_{4}, \mathrm{~N}_{2} \mathrm{O}$ and $\mathrm{CHCl}_{3}$. But only carbon dioxide and methane is produced in adequate quantities (khalil et al., 1990). Termites produce methane through the fermentation process in their intestines. The net efflux of methane from termites cannot be predicted due to the structure and the composition of their guts which favours homeoacetogenesis, for maintaining redox balance (Brune, 2006).

\section{Vegetation}

Methane is emitted from the vegetative foliage under aerobic conditions and thus adding to the overall methane budget in the atmosphere (Keppler et al., 2006). The methane emissions from plants were resulted from the methane derived from soil via internal air spaces or from the transpiration stream according to the initial observations of keppler in 2006. (Rusch and Rennenberg 1998) found that bark stems emitted methane when the methane concentration in the root zone was above ambient.

\section{Biomass burning}

Biomass burning is an important source for gases and particulates in the atmosphere. The type of gas produced will be totally depending on the type of biomass burned. Burning of biomass had a significant influence in the methane emission (Simpson et al., 2006). Burning of biomass will result in this reaction 
producing carbon dioxide as the end product in the complete combustion.

$$
\mathrm{CH}_{2} \mathrm{O}+\mathrm{O}_{2} \Rightarrow \mathrm{CO}_{2}+\mathrm{H}_{2} \mathrm{O}
$$

But in case of incomplete combustion the end product formed will be carbon compounds such as $\mathrm{CO}, \mathrm{CH}_{4}$, and other compounds. Most importantly the green house gases such as $\mathrm{CO}_{2}$ and methane formed via burning leads to global warming.

\section{Rice cultivation}

Rice fields contribute significantly to the global methane emission. Methane production in the rice field is occurring in the anoxic conditions. There are three pathways for the emission of methane from flooded paddy systems. They are diffusion in to the flood water, loss through ebullition, and diffusive transport through aerenchyma cells (yagi et al., 1997). More than 90 percent of methane emission is taking place in temperate rice (Schütz et al., 1989).

\section{Ruminants}

The animals like cattle, sheep and goats are herbivorous animals which regurgitate their food and chew it for the second time hence are called ruminants. They cannot digest the cellulose in the plants. But there is a great number of microorganisms present in their guts for doing this job. This bacteria's help in fermentation and as a result methane is formed as a by-product. In case of cattle and sheep, almost $92-98 \%$ of methane emits through their mouth and rest via flatus (Grainger et al., 2007).

\section{Manure}

The emissions from the manure are due to the presence of enteric bacteria that is excreted in to the manure by farm animals. The biogas which is produced from the animal dung is methane. But the good thing is that we can mostly control the unwanted methane emissions from manure through frequent removal of slurry from animal housing, gas tight covering for storage of manure, solid separation, aerobic treatment of stored slurry etc.

\section{Natural gas}

The natural gas is composed of more than $90 \%$ of methane. It is lost in the atmosphere during the extraction, processing and at supply. Such methane emissions account 2550Tg methane per year (Wuebbles and Hayhoe, 2002). This emission is mainly occurred through the leaks in pipe lines and during venting.

\section{Mitigation statergies}

The green house gases are responsible for the global warming. So by the control of emissions of these gases will reduce the risk of dangerous climate change. This can be mainly achieved by the control of methane because each unit of methane is $21-25 \%$ more powerful than $\mathrm{CO}_{2}$ over a 100 year time horizon (Smith et al., 2010). One of the most important cultural practices which are followed in rice cultivation is irrigation. According to (Wassmann et al., 1995) an aeration period which is in the midseason of tillering can reduce methane emission with the increase of rice yield. Some cultural practices which disturb the soil (tillage, weeding, transplanting, harrowing) can release the methane which is entrapped in the soil. A very high dose of sulphate containing fertilizer can reduce the methane production in the soil. But high sulphate concentration may affect plant growth and yield. Most of the soils are also responsible methane production. But a soil with a redox potential less than $-150 \mathrm{mV}$ can produce significant amount of methane. It may take weeks to produce methane from acid soils but in case 
of alkaline soil methane production will occur within hours.

The emissions of greenhouse gases from fossil fuels can be controlled by some energy efficient methods like fuel switching from fossil fuels to biomass fuels, from a high to lower carbon density fuel, carbon capture and storage, use of renewable energy etc. nuclear power generation is another option but the problems of nuclear waste storage is a serious problem. The emission of methane caused from the loss of natural gas through leakages can be solved by tracking down and removing all leaks in all mining and supply systems of fossil fuel industry. The methane should be captured and used for energy production. The methane which is trapped in the mines can be captured by drilling before the mining starts. It can be done half a year to several years before mining. Methane emissions from animals can be controlled if breeding programmes result in high milk and meat yield and high reproduction. By changing the livestock feed as a protein rich feed is another alternative to control methane emission from livestock.

Methane which is produced from the manure can be controlled by reducing fermentation by storing it in a dry and cool place. Liquid or slurry storage can also be practiced. Spreading of manure can reduce methane emissions by $10-35 \%$. The losses from burning of biomass can be reduced by improved burning of fuel wood, reducing deforestation, reduced agricultural wwaste and savanna burning etc.

Conclusion of the is as follows:

As per many research evidences, for an effectual impact, it has been recommended that for agricultural meditated green house gases such as methane, nitrate reductase, water vapour, etc. may be monitored and based on such observation crop commodity would be decided by the government and this may lead to production of underutilized crops also and possibly greenhouse gases emissions may be reduced.

\section{References}

Adhya, T.K., K. Bharati, S.R. Mohanty, B. Ramakrishnan, V.R. Rao, N. Sethunathan and R. Wassmann (2000) Methane emission from rice fields at Cuttack, India. Nutrient Cyc Agroecosyst, 58(1-3):95-105.

Agrawal, M. and S.B. Agrawal (1989) Phytomonitoring of air pollution around a thermal power plant. Atoms. Environ 23: 763- 769.

Bignell, D.E. and P. Eggleton (2000) Termites in ecosystems. In Termites: evolution, sociality, symbioses, ecology, Springer, Dordrecht. 363-387

Blake, D.R. and F.S. Rowland (1988) Continuing worldwide increase in tropospheric methane, 1978 to 1987. Science, 239(4844):1129-1131.

Brune, A. and M.Ohkuma (2010) Role of the termite gut microbiota in symbiotic digestion. In Biology of termites: a modern synthesis. Springer, Dordrecht, 439-475

Christensen, T.R., A. Ekberg, L.Ström, M. Mastepanov, N. Panikov, M. Öquist, B.H. Svensson, H. Nykänen, P.J. Martikainen and H. Oskarsson (2003) Factors controlling large scale variations in methane emissions from wetlands. Geophysical Res Letters, 30(7).

Cicerone, R.J. and R.S. Oremland (1988) Biogeochemical aspects of atmospheric methane. Global biogeochemical cycles, 2(4):299-327.

Grainger, C., T. Clarke, S.M. McGinn, M.J. Auldist, K.A. Beauchemin, M.C. Hannah, G.C. Waghorn, H. Clark and 
R.J. Eckard (2007). Methane emissions from dairy cows measured using the sulfur hexafluoride (SF6) tracer and chamber techniques. $J$. Dairy Sci, 90(6):2755-2766.

Houghton, J.T. ed., (1996). Climate change 1995: The science of climate change: contribution of working group I to the second assessment report of the Intergovernmental Panel on Climate Change (Vol. 2). Cambridge University Press.

Keppler, F., J.T. Hamilton, M. Braß and T. Röckmann, (2006) Methane emissions from terrestrial plants under aerobic conditions. Nature, 439(7073): 187.

Khalil, M.A.K. and R.A., Rasmussen (1990). Atmospheric methane: recent global trends. Environ. Sci. Technol. 24(4): 549-553.

Le Mer, J. and P. Roger (2001) Production, oxidation, emission and consumption of methane by soils: a review. European J Soil Biol. 37(1): 25-50.

MacDonald, J.A., D. Fowler, K.J. Hargreaves, U. Skiba, I.D. Leith, and M.B., Murray (1998) Methane emission rates from a northern wetland; response to temperature, water table and transport. Atmospheric Environ, 32(19): 3219-3227.

Mayer, H.P. and R. Conrad (1990) Factors influencing the population of methanogenic bacteria and the initiation of methane production upon flooding of paddy soil. FEMS Microbiology Ecol, 6(2): 103-111.

Rusch, H. and H. Rennenberg (1998) Black alder (Alnus glutinosa (L.) Gaertn.) trees mediate methane and nitrous oxide emission from the soil to the atmosphere. Plant and Soil, 201(1): 17.

Schütz, H., A. Holzapfel- Pschorn, R. Conrad, H. Rennenberg and W. Seiler (1989_. A 3- year continuous record on the influence of daytime, season, and fertilizer treatment on methane emission rates from an Italian rice paddy. J. Geophysical Res: Atmospheres, 94: 16405-16416.

Simpson, I.J., F.S. Rowland, S. Meinardi and D.R. Blake (2006) Influence of biomass burning during recent fluctuations in the slow growth of global tropospheric methane. Geophysical Res Letters, 33(22).

Smith, P., Reay, D. and A. Van Amstel eds. (2010) Methane and climate change. Routledge.

Wassmann, R., H.U. Neue, R.S. Lantin, M.J. Javellana, R. Diego, H. Hoffmann, H. Papen, and H. Rennenberg (1995). Methane emissions from rainfed rice fields. In Fragile lives in fragile ecosystems: proceedings of the International Rice Research Conference (pp. 217-225).

Wuebbles, D.J. and K., Hayhoe (2002) Atmospheric methane and global change. Earth-Science Reviews, 57:177-210.

Yagi, K., H. Tsuruta, and K. Minami (1997) Possible options for mitigating methane emission from rice cultivation. Nutrient Cycl Agroecosyst. 49:213-220.

\section{How to cite this article:}

Jencymol Thomas, Arun Kumar and Ashvani Kumar. 2020. Agricultural Methane Emissions: Consequences and Mitigations. Int.J.Curr.Microbiol.App.Sci. 9(02): 729-733. doi: https://doi.org/10.20546/ijcmas.2020.902.089 